\title{
KEY SKILLS IN BUSINESS COMMUNICATION - PERSUASION
}

\author{
Elena CIORTESCU ${ }^{\text {** }}$ \\ a) Alexandru Ioan Cuza University, Faculty of Economics and Business \\ Administration, Iași, Romania
}

Please cite this article as:

Article History:

Ciortescu, E., 2020. Key skills in business Received: 16 September 2020 communication - persuasion. Review of Economic Accepted: 20 October 2020 Studies and Research Virgil Madgearu, 13(2), pp.37-50.

doi: 10.24193/RVM.2020.13.59.

\begin{abstract}
While public speaking has been acknowledged as art due to the power it exerts in affecting people's attitudes and beliefs, the relevance of the ability to persuade goes well beyond the area of oral communication. People need to persuade their peers on both personal and professional matters. Consequently, if we refer to the area we are particularly interested in, i.e. business, we may assume that persuasion is undoubtedly among the skills that students need to acquire in order to cope with the challenges which occur in various professional (and not only) contexts. Consequently, the aim of this paper is to explore the areas which require the use of persuasive strategies and to discuss the means by which business students could be enabled to acquire the ability to successfully use them. In the first part of the paper, the main theoretical aspects related to communication, business communication and persuasion will be discussed. In the second part of the paper, some strategies for developing persuasion skills among business students will be identified. Finally, conclusions on the best practices in dealing with persuasion in Business communication classes will be drawn.
\end{abstract}

Key words: ESP; business communication; persuasion

JEL Classification: A1; A2; A12; A13; Y8

(C) 2020 Alma Mater Publishing House. All rights reserved.

* Corresponding author. E-mail address: crismonais@yahoo.com. 


\section{References:}

1. Bezos, J., 2010. What matters more than your talents, [online] Available at: https://jamesclear.com/great-speeches/what-mattersmore-than-your-talents-by-jeff-bezos [Accessed 12 September 2020].

2. Chan, M., 2020. English for Business Communication. London: Routledge.

3. Cuddon, J.A., 1998. The Penguin Dictionary of Literary Terms and Literary Theory: Penguin Books.

4. Dignen, B. and McMaster, I., 2013. Effective International Business Communication. London: Harper Collins.

5. Jackson, J., 2020. Introducing Language and Intercultural Communication, $2^{\text {nd }}$ ed. London: Routledge.

6. Literary Devices, 2020. Definition and Examples of Literary Terms. [online] Available at: <https://literarydevices.net/tricolon/> [Accessed 28 August 2020].

7. Mohan, B., 2019. Understanding Public Speaking - A Learner's Guide to Persuasive Oratory. London: Routledge.

8. Tikkanen, A., 2020. Jeff Bezos. [online] Available at: https://www. britannica.com/biography/Jeff-Bezos [Accessed 14 September 2020]. 